\title{
SOIL BACTERIAL BIODIVERSITY IN DEVELOPMENT OF SECONDARY LOGGED- OVER FOREST TO OIL PALM PLANTATION IN MINERAL SOIL OF BELAGA, SARAWAK
}

\author{
SHAMSILAWANI AHAMED BAKERI*; MOHD SHAWAL THAKIB MAIDIN ${ }^{\star}$ and \\ MOHD MAZMIRA MOHD MASRI*
}

\begin{abstract}
Conversion of forest to oil palm typically results in significant land changes within the soil, for example, extensive damage to the top soil, soil compaction and erosion. Such changes are often related to reductions within the biodiversity and abundance of the soil microbial communities. By using 165 rDNA and denaturing gradient gel electrophoresis, we investigated the microbial composition between oil palm plantations, at various stages of planting in mineral soil of Belaga, Sarawak in Malaysia, and forest ecosystem (biodiversity strip). Bacterial composition within biodiversity strips of secondary logged-over forests was mostly dominated by unclassified bacteria, Acidobacteria, and Actinobacteria followed by $\alpha$-Proteobacteria whereas oil palm management areas were most commonly consisted of unclassified bacteria, Firmicutes, $\beta$-Proteobacteria, Actinobacteria, Acidobacteria and Chloroflexi. In a newly developed oil palm plantation, $\mathrm{pH}$ factor with the addition of fertiliser during land clearing altered the bacteria composition, affecting several phyla especially Acidobacteria, and with increasing $\mathrm{pH}$, the population showed an abundance of Firmicutes, $\beta$-Proteobacteria, $\gamma$-Proteobacteria, Chloroflexi, and Bacteroidetes. Shifts in the bacterial community of the oil palm plantation, especially with the increasing number of the phylum Firmicutes, $\beta$-Proteobacteria, Bacteroidetes and the decreasing number of $\alpha$-Proteobacteria caused by the slight increase of $\mathrm{pH}$ values indicated that changes of soil properties introduced by field management (e.g., fertiliser application) somehow affects bacterial composition. Nevertheless, the method of intercropping oil palm with black pepper and pineapple, during oil palm aged 4.5 years, showed increasing emergence of minor phyla from Gemmatimonadetes, Planctomycetes, Chlamydiae and Cyanobacteria, which contributes to the diverse variations of new phylum to the microbial diversity of the oil palm area indicating this method as a sustainable system for the oil palm management. Overall, there is a need for further research in using sustainable methods such as a suitable intercropping system that can positively improve soil fertility and a balanced long-term usage of biofertilisers and chemical fertilisers, which can enhance the biodiversity of the bacterial community and contributes to the sustainable development of oil palm plantations.
\end{abstract}

Keywords: microbial biodiversity, 16S rDNA, denaturing gradient gel electrophoresis, oil palm plantation.

Date received: 8 August 2018; Sent for revision: 9 August 2018; Received in final form: 9 December 2018; Accepted: 13 August 2019.

\section{INTRODUCTION}

Malaysian Palm Oil Board,

6 Persiaran Institusi, Bandar Baru Bangi,

43000 Kajang, Selangor, Malaysia.

E-mail: shila@mpob.gov.my
Soil microbes are associated with biochemical processes of the soil including organic matter deterioration, humus development and nutrient cycle that played an important role in conserving 
soil productivity (Curtis et al., 2002). Conversion of secondary forest to agricultural cultivation such as oil palm plantations can cause rapid changes in the soil microbial populations and activities. Oil palm is becoming the world's most rapidly expanding tropical crop, with increased expansion of oil palm planted area in Malaysia from 5.74 million hectares in 2016 to 5.81 million hectares in 2017 (Kushairi et al., 2018). The development to oil palm plantations has led to conversion of tropical forest, logged-over forest and peatlands (Koh et al., 2011; Carlson et al., 2012). Most of these soil microbial populations are sensitive to the soil changes; therefore, some microbiological parameters such as microbial biodiversity, maybe used as an indicator for soil quality (Fierer et al., 2007a). Microbes decomposing carbon-based litter are a vital constituent of global biogeochemical cycles (Burgin et al., 2011; van der Heijden et al., 2008; Zhang et al., 2013), breaking down complicated organic materials and releasing $\mathrm{CO}_{2}$ to the atmosphere via respiration and causing nutrients accessible to promote primary production (Dubinsky et al., 2010; Nielsen et al., 2011).

Conventional methods for microbial identification based on phenotypic characteristics (e.g. morphology and biochemistry) are generally less accurate in identifying species. Development of molecular and genomic tools have recently opened a window to assess the diversity and composition of these communities (Caporaso et al., 2011; Fierer et al., 2007b). Most target the $16 \mathrm{~S} r$ RNA gene by polymerase chain reaction (PCR) amplification and subsequent analysis using clone libraries (He et al., 2006), denaturing gradient gel electrophoresis (DGGE) (Muyzer et al., 1993), terminal restriction fragment length polymorphism (T-RFLP) (Fierer et al., 2007b) and the advancement of next generation sequencing (NGS). NGS or high-throughput sequencing has become a powerful sequencing tool which led to the establishment in the field of 'metagenomics'. Metagenomics is the genomic analysis of microbes by direct DNA extraction and DNA cloning from an assemblage of microorganisms (Oulas et al., 2015). NGS consists of different platforms, such as Roche 454 pyrosequencing and Illumina/Solexa where, Roche 454 pyrosequencing has increase its average read lengths to $\sim 500$ base pairs compared to Illumina which only has $\sim 150$ base pairs.

Microbial diversity, in the structural and compositional changes among communities sampled, has been used to evaluate the impact of land use change in a wide range of studies (Ding et al., 2013; Suleiman et al., 2013). In this research, we aim to investigate the microbial composition between oil palm plantations, at various stages of planting in mineral soil of Belaga, Sarawak, in Malaysia and forest ecosystem by using 16S rDNA and denaturing gradient gel electrophoresis. The information acquired from these molecular tools, can evaluate the changes in soil or environment and determine the main drivers of change in microbial diversity (Wakelin et al., 2008). This knowledge can also be used to classify the taxa and indicators for monitoring the effect of land use change.

\section{MATERIALS AND METHOD}

\section{Soil Sampling}

Sampling for microbial biodiversity study at Sungai Asap, Belaga, Sarawak was conducted at four sites namely Biodiversity Strip 1 (S1, hilly secondary jungle), Strip 2 (S2, disturbed secondary jungle), Strip 3 (S3, riparian area) and oil palm (OP) planted area to investigate the bacterial composition between oil palm cultivated and uncultivated areas (Figure 1).Sampling was carried out at respective GPS points from depth of $0-15 \mathrm{~cm}$ (Table 1). The distance between each GPS point for OP was approximately from $40 \mathrm{~m}$ to $200 \mathrm{~m}$ on average whereas biodiversity strips sampling points were about $100 \mathrm{~m}$ apart. A total of 40 soil samples were collected from hilly secondary jungle (10), disturbed secondary jungle (10), riparian area (10) and oil palm plantation (10). Four soil replicates were collected from each GPS sampling point. All of the four replicates of soil samples from the same sampling point were pooled together and homogenised. Fifty grams of soil samples were collected in $50 \mathrm{ml}$ sterile falcon tubes and transported in an ice box and subsequently kept at $10^{\circ} \mathrm{C}$ prior to laboratory analysis. Oil palm area was intercropped with pepper and pineapple during July 2012. Sampling for Strip 3 was stopped after fourth sampling (OP 2.5 years).

\section{Extraction of DNA from Soil}

Microbial DNA were extracted directly from soil, using GeneMatrix Soil DNA Purification kit (EURx Ltd., Poland) (Agnieszka et al., 2012). DNA were quantified using Nanophotometer (Implen GMBH, Germany) with absorbance ratio of A260/ A280 for measurement of nucleic acids.

\section{PCR Amplification for Bacterial 16s rDNA}

Universal primers used were forward (f) with GC-clamps,341f(5'-cgc-ccg-ccg-cgc-gcg-gcg-ggcggg-gcg-ggg-gca-cgg-ggg-gcc-tac-gg-agg-cagcag-3') and reverse primers $907 \mathrm{r}$ ( $5^{\prime}$-ccc-cgt-caa-ttcatt-tga-gtt-t-3') (Muyzer et al., 1993).

\section{Denaturing Gradient Gel Electrophoreis (DGGE) for Bacterial 16s rDNA}

PCR products were electrophoresed on $6 \%(\mathrm{w} / \mathrm{v})$ polyacrylamide (37.5:1; acrylamide:bisacrylamide) and separated with a denaturing gradient of $40 \%$ to 


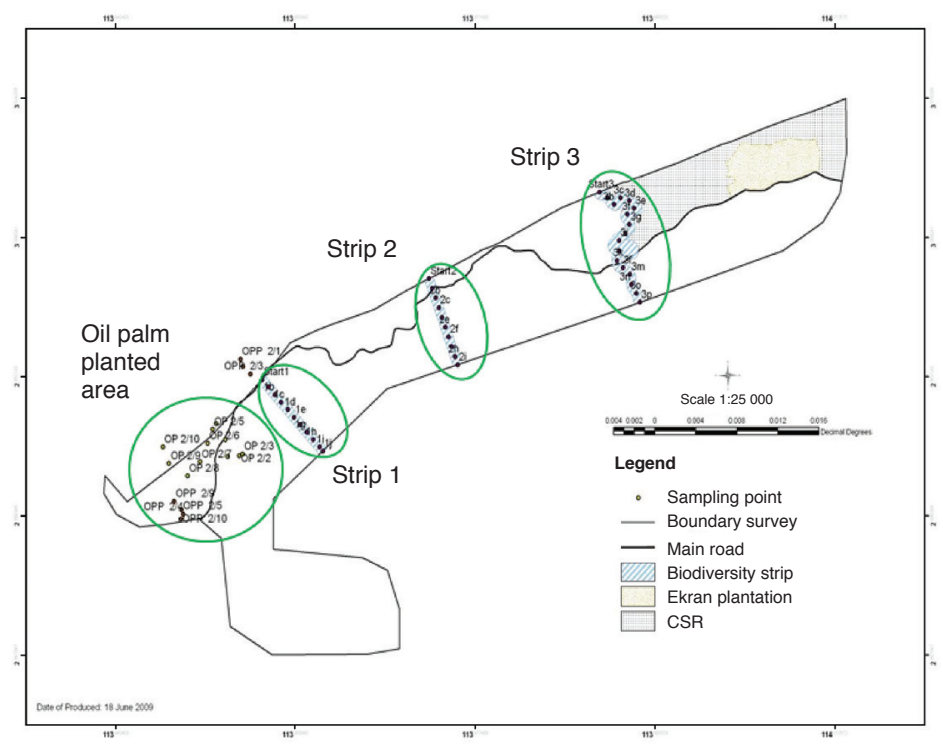

Figure 1. Sampling points studied in Sungai Asap, Belaga, Sarawak.

TABLE 1. GLOBAL POSITIONING SYSTEM (GPS) SAMPLING POINTS OF SITES STUDIED IN BELAGA, SARAWAK

\begin{tabular}{|c|c|c|c|c|}
\hline No. & Sites & Forest type & Sampling points & Location on GPS \\
\hline 1. & $\begin{array}{l}\text { Oil palm cultivated } \\
\text { area }\end{array}$ & Lowlands & $\begin{array}{c}1 \\
2 \\
3 \\
4 \\
5 \\
6 \\
7 \\
8 \\
9 \\
10\end{array}$ & $\begin{array}{l}\mathrm{N}, 2^{\circ} 59^{\prime} 6.71^{\prime \prime} \mathrm{E}, 113^{\circ} 57^{\prime} 11.976^{\prime \prime} \\
\mathrm{N}, 2^{\circ} 59^{\prime} 7.0^{\prime \prime} \mathrm{E}, 113^{\circ} 57^{\prime} 16.0^{\prime \prime} \\
\mathrm{N}, 2^{\circ} 59^{\prime} 7.5^{\prime \prime} \mathrm{E} 113^{\circ} 57^{\prime} 17.2^{\prime \prime} \\
\mathrm{N} 2^{\circ} 59^{\prime} 17^{\prime \prime} \mathrm{E} 113^{\circ} 57^{\prime} 7.9^{\prime \prime} \\
\mathrm{N} 2^{\circ} 59^{\prime} 15.2^{\prime \prime} \mathrm{E} 113^{\circ} 57^{\prime} 6.7^{\prime \prime} \\
\mathrm{N} 2^{\circ} 59^{\prime} 10.6^{\prime \prime} \mathrm{E} 113^{\circ} 57^{\prime} 5.3^{\prime \prime} \\
\mathrm{N} 2^{\circ} 59^{\prime} 5.3^{\prime \prime} \mathrm{E} 113^{\circ} 57^{\prime} 2.2^{\prime \prime} \\
\mathrm{N} 2^{\circ} 59^{\prime} 00.8^{\prime \prime} \mathrm{E} 113^{\circ} 56^{\prime} 57.6^{\prime \prime} \\
\mathrm{N} 2^{\circ} 59^{\prime} 4.6^{\prime \prime} \mathrm{E} 113^{\circ} 56^{\prime} 52^{\prime \prime} \\
\mathrm{N} 2^{\circ} 59^{\prime} 09.4^{\prime \prime} \mathrm{E} 113^{\circ} 57^{\prime} 49.2^{\prime \prime}\end{array}$ \\
\hline 2. & Biodiversity Strip 1 & $\begin{array}{l}\text { Secondary } \\
\text { jungle, hilly } \\
\text { area, } \\
\text { undisturbed }\end{array}$ & $\begin{array}{c}1 \\
2 \\
3 \\
4 \\
5 \\
6 \\
7 \\
8 \\
9 \\
10\end{array}$ & 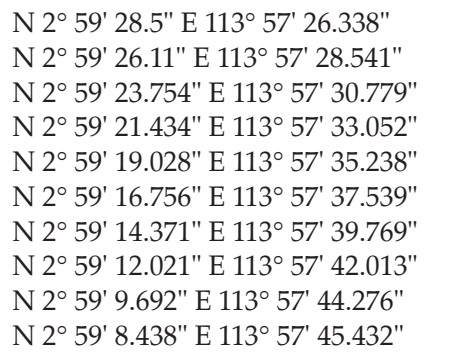 \\
\hline 3. & Biodiversity Strip 2 & $\begin{array}{l}\text { Secondary } \\
\text { jungle, } \\
\text { disturbed }\end{array}$ & $\begin{array}{c}1 \\
2 \\
3 \\
4 \\
5 \\
6 \\
7 \\
8 \\
9 \\
10\end{array}$ & $\begin{array}{l}\mathrm{N} 3^{\circ} 0^{\prime} 2.328^{\prime \prime} \mathrm{E} 113^{\circ} 58^{\prime} 23.176^{\prime \prime} \\
\mathrm{N} 2^{\circ} 59^{\prime} 59.381^{\prime \prime} \mathrm{E} 113^{\circ} 58^{\prime} 23.874^{\prime \prime} \\
\mathrm{N} 2^{\circ} 59^{\prime} 56.343^{\prime \prime} \mathrm{E} 113^{\circ} 58^{\prime} 25.041^{\prime \prime} \\
\mathrm{N} 2^{\circ} 59^{\prime} 53.296^{\prime \prime} \mathrm{E} 113^{\circ} 58^{\prime} 26.183^{\prime \prime} \\
\mathrm{N} 2^{\circ} 59^{\prime} 50.247^{\prime \prime} \mathrm{E} 113^{\circ} 58^{\prime} 27.321^{\prime \prime} \\
\mathrm{N} 2^{\circ} 59^{\prime} 47.204^{\prime \prime} \mathrm{E} 113^{\circ} 58^{\prime} 28.474^{\prime \prime} \\
\mathrm{N} 2^{\circ} 59^{\prime} 44.154^{\prime \prime} \mathrm{E} 113^{\circ} 58^{\prime} 29.616^{\prime \prime} \\
\mathrm{N} 2^{\circ} 59^{\prime} 41.099^{\prime \prime} \mathrm{E} 113^{\circ} 58^{\prime} 30.752^{\prime \prime} \\
\mathrm{N} 2^{\circ} 59^{\prime} 38.036^{\prime \prime} \mathrm{E} 113^{\circ} 58^{\prime} 31.859^{\prime \prime} \\
\mathrm{N} 2^{\circ} 59^{\prime} 35.442^{\prime \prime} \mathrm{E} 113^{\circ} 58^{\prime} 32.754^{\prime \prime}\end{array}$ \\
\hline 4. & Biodiversity Strip 3 & Riparian area & $\begin{array}{c}1 \\
2 \\
3 \\
4 \\
5 \\
6 \\
7 \\
8 \\
9 \\
10\end{array}$ & $\begin{array}{l}\text { N } 3^{\circ} 0^{\prime} 27.726^{\prime \prime} \text { E } 113^{\circ} 113^{\circ} 59^{\prime} 25.363^{\prime \prime} \\
\text { N } 3^{\circ} 0^{\prime} 25.628^{\prime \prime} \text { E } 113^{\circ} 113^{\circ} 59^{\prime} 27.742^{\prime \prime} \\
\text { N } 3^{\circ} 0^{\prime} 27.69^{\prime \prime} \text { E } 113^{\circ} 113^{\circ} 59^{\prime} 30.025^{\prime \prime} \\
\text { N } 3^{\circ} 0^{\prime} 26.761^{\prime \prime} \text { E } 113^{\circ} 113^{\circ} 59^{\prime} 33.044^{\prime \prime} \\
\text { N } 3^{\circ} 0^{\prime} 24.38^{\prime \prime} \text { E } 113^{\circ} 113^{\circ} 59^{\prime} 34.681^{\prime \prime} \\
\text { N } 3^{\circ} 0^{\prime} 22.522^{\prime \prime} \text { E } 113^{\circ} 113^{\circ} 59^{\prime} 32.335^{\prime \prime} \\
\text { N } 3^{\circ} 0^{\prime} 19.337^{\prime \prime} \text { E } 113^{\circ} 113^{\circ} 59^{\prime} 33.059^{\prime \prime} \\
\text { N } 3^{\circ} 0^{\prime} 16.558^{\prime \prime} \text { E } 113^{\circ} 113^{\circ} 59^{\prime} 31.706^{\prime \prime} \\
\text { N } 3^{\circ} 0^{\prime} 14.364^{\prime \prime} \text { E } 113^{\circ} 113^{\circ} 59^{\prime} 29.502^{\prime \prime} \\
\text { N } 3^{\circ} 0^{\prime} 11.12^{\prime \prime} \text { E } 113^{\circ} 113^{\circ} 59.519^{\prime \prime}\end{array}$ \\
\hline
\end{tabular}


$80 \%$ (100\% denaturant corresponds to $7 \mathrm{M}$ urea and $40 \%$ [vol/vol] deionised formamide) run at $60 \mathrm{~V}, 16 \mathrm{hr}$.

\section{Recovery and Purification of DNA}

DNA bands from DGGE were cut out using a sterile blade and collected in a $1.5 \mathrm{ml}$ microcentrifuge tube containing $50 \mu \mathrm{lddH_{2 }} \mathrm{O}$. For DNA elution, the excised gel with DNA were incubated overnight at $4^{\circ} \mathrm{C}$. Eluted DNA was purified using QIAquick gel extraction kit (QIAGEN, Inc., Valencia, CA), according to the kit's protocol.

\section{PCR Amplification of Purified Band from DGGE}

DNA from the DGGE gel successfully excised, clean and purified was amplified again using PCR with forward (F) primers 165 rDNA, without GC-clamps (GC). PCR products from agarose gel were again cut and purified using QIAquick Gel Extraction Kit, as mentioned above. The purified DNA was sequenced in both directions with the same primers without GC as used in the PCR amplification step above.

\section{Sequencing Analysis}

The PCR products were sent to First Base Laboratories (Malaysia) for sequencing analysis. Nucleotide-nucleotide basic logic alignment search tool (BLASTn) service of the NCBI GenBank database was used to identify the nearest relatives of the partially sequenced $16 S$ rDNA genes of excised dominant bands.

\section{Statistical Analysis and Biodiversity Indices}

The Shannon-Weaver Biodiversity index is a common diversity index which increases with species number and is highest when the mass is distributed more evenly over the species (Hill, 1973). The BergerParker Dominance index expresses the proportional importance of the most abundant species (the dominant species). It is a numerical measure of the most abundant species in the formula, $\mathrm{D}=\mathrm{N}_{\max }$ $/ \mathrm{N}$, where $N_{\max }$ is the number of individuals in the most abundant species, and $N$ is the total number of individuals in the sample (Hill, 1973). Statistics for the significant difference was done by means of one-way analysis of variance (ANOVA) and post hoc Tukey test $(\mathrm{p}<0.05)$. Principal component analysis (PCA) with Pearson correlation, was used using Excel combined XLStat for correlation analysis.

\section{RESULTS AND DISCUSSION}

\section{Biodiversity Indices}

Time-course of Shannon-Weaver bacterial biodiversity index showed an increase after clean- clearing to early planting of oil palm, from October 2008 to July 2009, from 7.423 to 7.627 , respectively (Table 2). Shannon-Weaver indices for biodiversity strip was high during early planting (July 2009). Further increase in index for the OP planted area, was observed when oil palm was from 2.5 years old (April 2010) to 3.5 years old (June 2011), with the increase index value from 7.773 to 8.323 , respectively. At 4.5 years and 5.5 years, the biodiversity index slightly fluctuated but remained steadily at index 8.279 (Table 2). Berger-Parker Dominancy index showed generally microbial diversity increased as the age of the oil palm increased to 5.5 years (Table 3). This is supported by Dilly et al. (2004), which documented that the increase in ShannonWeaver Biodiversity index indicates that in general, microbial diversity intensifies as the decomposition of organic material progresses as these provide nutrient rich environment for the microbes to thrive. Indices from the Shannon-Weaver Biodiversity index showed index values from OP area were significantly different from that of biodiversity strips until June 2013 (Table 2).

\section{Prevalence Percentage of Soil Prokaryotic Phyla}

Percentage occurrence of phyla levels in Figures 2 to 7 , indicated that, before clean-clearing (October 2008) until palm reached 5.5 years (June 2013), unclassified bacteria was the dominant phylum amongst the prokaryotic population in all sites including the oil palm cultivated area. The unclassified bacteria group are species of bacteria which are not assigned to any classification of genus or species by the taxonomy classifier or BlastN, based on their sequence similarities/blasts. Before clean-clearing (October 2008) Acidobacteria group was the second most dominant in the OP area, while the Actinobacteria, Firmicutes, and $\alpha$-Proteobacteria group were found in all biodiversity strip areas (Figure 2). In OP cultivated area, the phyla consisted of 10 groups compared to 5-7 phylum groups in strip areas. The presence of phylum beta, gamma and delta proteobacteria were observed in the OP area but they were not found in the biodiversity strips area.

Eight months after clean-clearing in July 2009, there was an abundance of Firmicutes $(25 \%)$ in OP cultivated area, followed by Acidobacteria (6\%) and $\beta$-Proteobacteria (6\%) (Figure 3). Actinobacteria was predominant in biodiversity strips, S1, S2 and S3 with 15\%, 19\% and 11\%, respectively (Figure $3)$. In the 1.5-year old OP area, phylum decreased to nine groups, compared to 11 phylum groups in strip areas. In OP cultivated area, the abundance of Firmicutes seemed to be related with the abundance of organic materials after clean-clearing and also with the increased application of fertiliser CIRP (rock phosphate) used in March and April 2009. 
TABLE 2. SHANNON-WEAVER BIODIVERSITY INDICES FOR SOIL PROKARYOTES ON MINERAL SOIL SAMPLED FROM SUNGAI ASAP, BELAGA, SARAWAK

\begin{tabular}{|c|c|c|c|c|}
\hline \multirow[t]{2}{*}{ Sites } & OPP & S1 & S2 & S3 \\
\hline & \multicolumn{4}{|c|}{ Shannon-Weaver Biodiversity Index } \\
\hline $\begin{array}{l}\text { Oct. } 2008 \\
\text { (logged-over forest) }\end{array}$ & $7.423 \pm 0.043^{a}$ & $7.001 \pm 0.056^{\mathrm{b}}$ & $6.789 \pm 0.014^{\mathrm{c}}$ & $6.276 \pm 0.01^{\mathrm{d}}$ \\
\hline $\begin{array}{l}\text { July } 2009 \\
\text { (OP } 1.5 \text { yr) }\end{array}$ & $7.627 \pm 0.008^{\mathrm{a}}$ & $8.26 \pm 0.023^{\mathrm{b}}$ & $8.002 \pm 0.014^{c}$ & $8.070 \pm 0.011^{c}$ \\
\hline $\begin{array}{l}\text { April } 2010 \\
\text { (OP } 2.5 \mathrm{yr} \text { ) }\end{array}$ & $7.773 \pm 0.02^{\mathrm{a}}$ & $7.322 \pm 0.018^{\mathrm{b}}$ & $7.337 \pm 0.041^{\mathrm{c}}$ & $8.003 \pm 0.024^{\mathrm{d}}$ \\
\hline $\begin{array}{l}\text { June } 2011 \\
\text { (OP } 3.5 \text { yr) }\end{array}$ & $8.323 \pm 0.02^{\mathrm{a}}$ & $8.003 \pm 0.012^{\mathrm{b}}$ & $7.710 \pm 0.015^{\mathrm{c}}$ & - \\
\hline $\begin{array}{l}\text { July } 2012 \\
\text { (OP } 4.5 \text { yr) }\end{array}$ & $8.173 \pm 0.018^{\mathrm{a}}$ & $8.064 \pm 0.013^{b}$ & $7.939 \pm 0.01^{\mathrm{c}}$ & - \\
\hline $\begin{array}{l}\text { June } 2013 \\
\text { (OP } 5.5 \mathrm{yr} \text { ) }\end{array}$ & $8.279 \pm 0.018^{\mathrm{a}}$ & $8.141 \pm 0.014^{\mathrm{b}}$ & $8.064 \pm 0.016^{c}$ & - \\
\hline
\end{tabular}

Note: OP - oil palm area, OPP - oil palm plantation, S1- Biodiversity Strip 1, S2 - Biodiversity Strip 2, and S3 - Biodiversity Strip 3. Indices were compared using Tukey's Method. Shannon-Weaver Biodiversity indices with the different letters are significantly different at $\mathrm{p}<0.05$.

TABLE 3. BERGER-PARKER DOMINANCE INDICES FOR SOIL PROKARYOTES ON MINERAL SOIL SAMPLED FROM SUNGAI ASAP, BELAGA, SARAWAK

\begin{tabular}{|c|c|c|c|c|}
\hline \multirow[t]{2}{*}{ Sites } & OPP & S1 & S2 & S3 \\
\hline & \multicolumn{4}{|c|}{ Berger-Parker Dominance Index } \\
\hline $\begin{array}{l}\text { Oct. } 2008 \\
\text { (logged-over forest) }\end{array}$ & $0.5742 \pm 0.014^{\mathrm{a}}$ & $0.5822 \pm 0.019^{\mathrm{b}}$ & $0.6628 \pm 0.053^{c}$ & $0.5885 \pm 0.075^{\mathrm{d}}$ \\
\hline $\begin{array}{l}\text { July } 2009 \\
\text { (OP } 1.5 \text { yr) }\end{array}$ & $0.3958 \pm 0.011^{\mathrm{a}}$ & $0.2863 \pm 0.027^{b}$ & $0.3173 \pm 0.019^{c}$ & $0.5202 \pm 0.016^{\mathrm{d}}$ \\
\hline $\begin{array}{l}\text { April } 2010 \\
\text { (OP } 2.5 \mathrm{yr} \text { ) }\end{array}$ & $0.4735 \pm 0.029^{a}$ & $0.3545 \pm 0.019^{\mathrm{b}}$ & $0.4148 \pm 0.04^{\mathrm{c}}$ & $0.4894 \pm 0.027^{\mathrm{d}}$ \\
\hline $\begin{array}{l}\text { June } 2011 \\
\text { (OP } 3.5 \mathrm{yr} \text { ) }\end{array}$ & $0.5570 \pm 0.027^{a}$ & $0.5874 \pm 0.016^{\mathrm{b}}$ & $0.6600 \pm 0.021^{c}$ & - \\
\hline $\begin{array}{l}\text { July } 2012 \\
\text { (OP } 4.5 \mathrm{yr})\end{array}$ & $0.4718 \pm 0.022^{a}$ & $0.4807 \pm 0.014^{a}$ & $0.4887 \pm 0.018^{\mathrm{b}}$ & - \\
\hline $\begin{array}{l}\text { June } 2013 \\
\text { (OP } 5.5 \mathrm{yr} \text { ) }\end{array}$ & $0.3684 \pm 0.018^{\mathrm{a}}$ & $0.4681 \pm 0.016^{\mathrm{b}}$ & $0.6301 \pm 0.014^{c}$ & - \\
\hline
\end{tabular}

Note: OP - oil palm area, OPP - oil palm plantation, S1 - Biodiversity Strip 1, S2 - Biodiversity Strip 2, and S3 - Biodiversity Strip 3. Indices were compared using Tukey's Method. Berger-Parker Dominance indices with the different letters are significantly different at $\mathrm{p}<0.05$.

Firmicutes such as orders Bacillales and unclassified Firmicutes thriving in this area specifically enriched the level of phosphorus in plants with the capability to solubilise insoluble inorganic phosphate (mineral phosphate) compounds (Hayat et al., 2010).

Eight to 12 months later, when the oil palm was 2.5 to 3.5 years (April 2010 to June 2011), unclassified bacteria dominated the population from 51\%-58\% in all sites. Another predominant phylum, Actinobacteria dominated $12 \%-35 \%$ of the population in April 2010 (Figure 4), whereas Acidobacteria dominated about $14 \%-15 \%$ in June 2011 (Figure 5) in all sites. In OP area of 2.5 years, phylum consisted of 10 groups compared to nine phylum groups of strip areas. There was an increase in the phylum Firmicutes and $\beta$-Proteobacteria group when palms were at 4.5 and 5.5 years, respectively (Figures 6 and 7). MPOB F1 fertiliser $\left(1.75 \mathrm{~kg} \mathrm{palm}^{-1}\right)$ was added during May, one to two months before soil was sampled in July 2012 and June 2013 (Table 5), which may increase the occurrence of these two phyla. The phylum Firmicutes is usually involve in nitrogen fixation in plants, and also as a phosphate solubilising bacteria, specifically enhancing the phosphorus level of plants (Hayat et al., 2010). Meanwhile, $\beta$-Proteobacteria are 


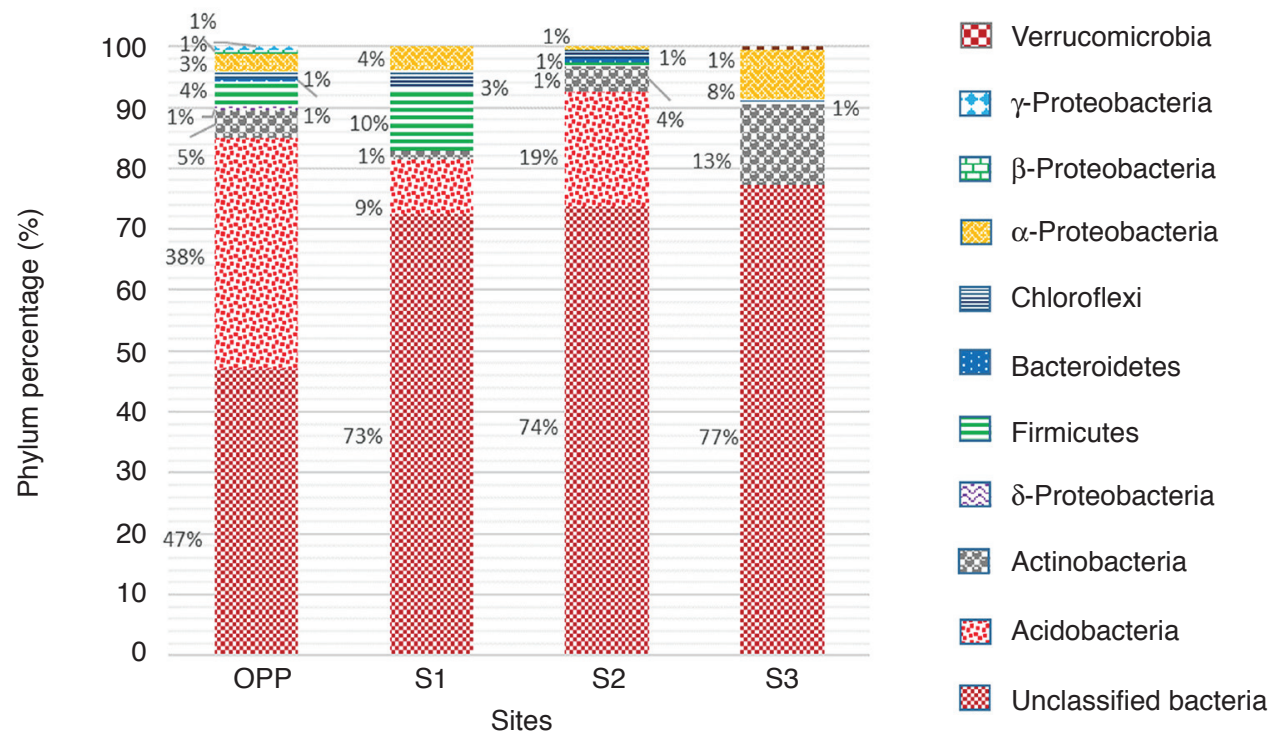

Note: (a) OPP - oil palm cultivable area, (b) S1 - Strip 1, (c) S2 - Strip 2 and (d) S3 - Strip 3.

Figure 2. Prevalence of soil bacterial phyla at Belaga from October 2008 for biodiversity strips versus oil palm sampled from Sungai Asap, Belaga, Sarawak.

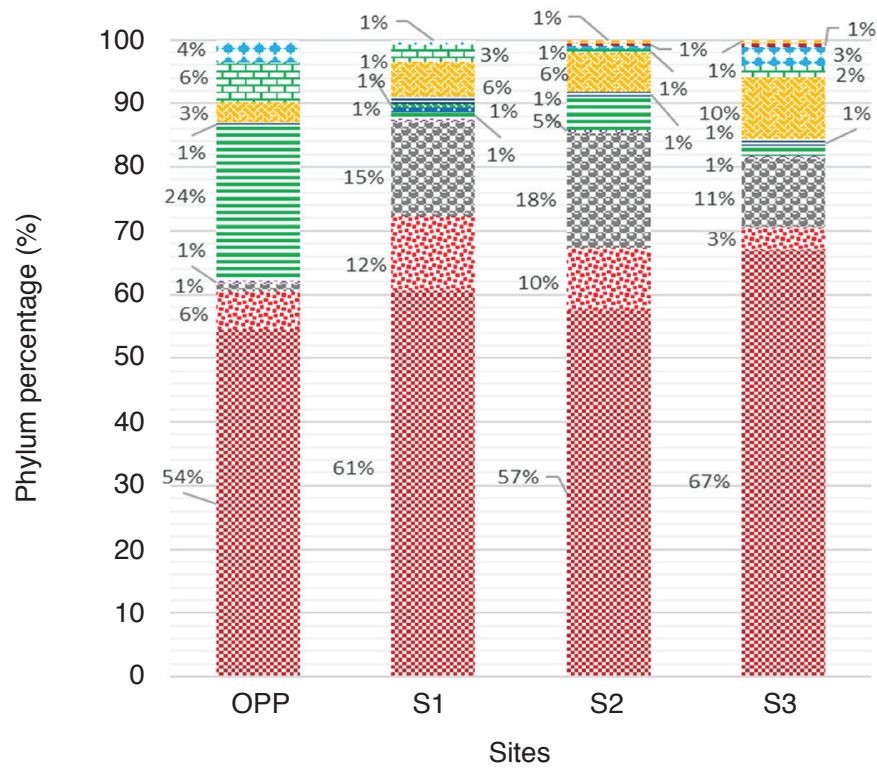

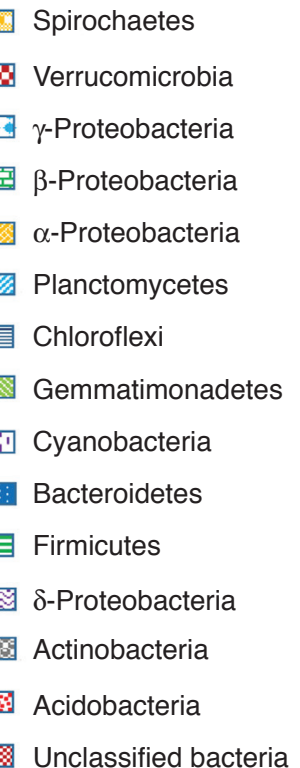

Unclassified bacteria

Note: (a) OPP - oil palm aged 1.5 years, (b) S1 - Strip 1, (c) S2 - Strip 2 and (d) S3 - Strip 3.

Figure 3. Prevalence of soil bacterial phyla at Belaga from July 2009 for biodiversity strip versus oil palm sampled from Sungai Asap, Belaga, Sarawak.

chemoorganotrophs and colonises plant roots acting as nitrogen fixers (Hilton et al., 2013). At 4.5 years, intercropping in the OP area with peppers and pineapple caused an increased in phylum diversity of the OP area, with 15 phyla compared to 10-11 phyla in strip areas, where OP showed an increase of minor phylum groups.

Table 4 indicates that the number of species increased steadily from logged-over, after cleanclearing, and under oil palms aged 1.5, 2.5, 3.5, 4.5 and 5.5 years (October 2008 until July 2013) with values of 85, 159, 116,186, 293 and 230, respectively. As for the biodiversity Strip 2 the number of species fluctuates and remained the lowest until July 2013. The reduced species number in Strip 2 was caused by the disturbance of the natives colonising, hunting and burning hills for growing paddy and oil palm in the area during July 2009. Towards palms age of 4.5 and 5.5 years the oil palm area exhibited high species number of $\beta$-Proteobacteria, Bacteroidetes Firmicutes and Chloroflexi compared to strips area (Table 4). According to a study by Fierer 


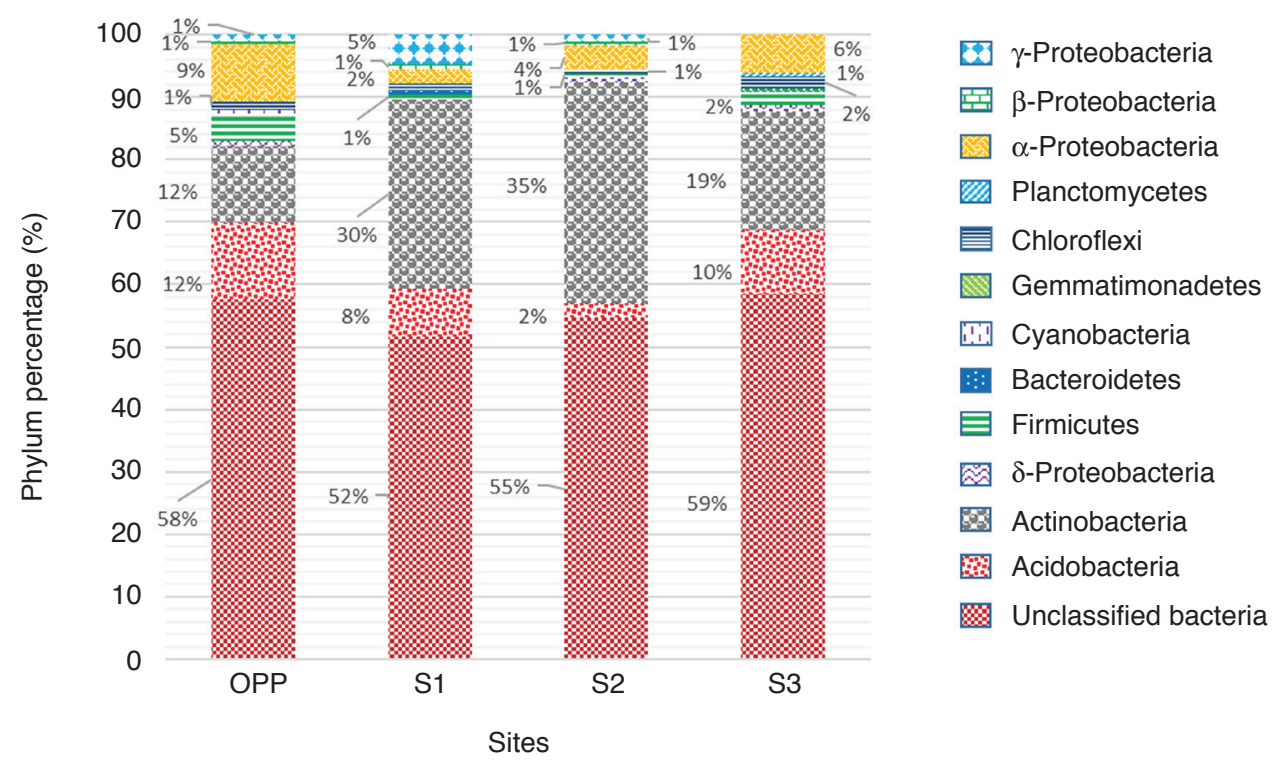

Note: (a) OPP - oil palm aged 2.5 years, (b) S1 - Strip 1, (c) S2 - Strip 2 and (d) S3 - Strip 3.

Figure 4. Prevalence of soil bacterial phyla at Belaga from April 2010 for biodiversity strips versus oil palm sampled from Sungai Asap, Belaga, Sarawak.
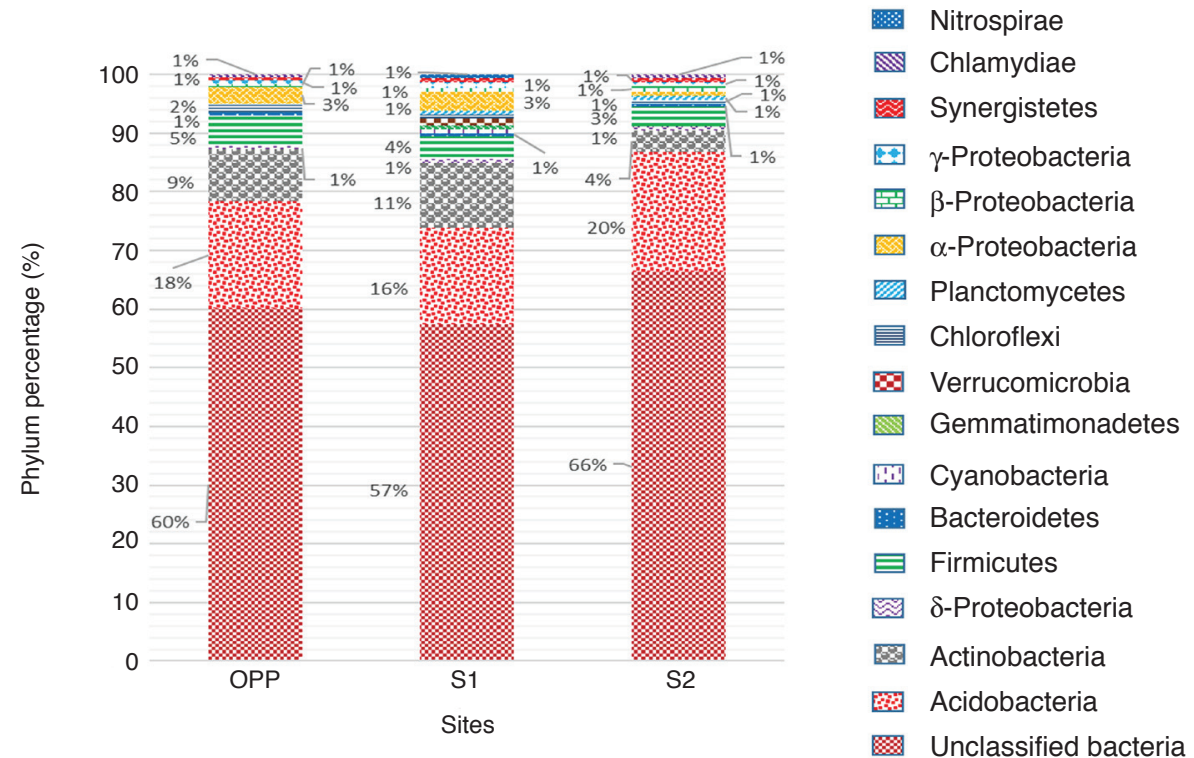

Note: (a) OPP - oil palm aged 3.5 years, (b) S1 - Strip 1, (c) S2 - Strip 2 and (d) S3 - Strip 3.

Figure 5. Prevalence of soil bacterial phyla at Belaga from June 2011 for biodiversity strips versus oil palm sampled from Sungai Asap, Belaga, Sarawak.

(2007a), the available carbon (C) in the soil was positively correlated with the relative abundance of Bacteroidetes and Betaproteobacteria. During these years, there were also appearances of several minor phyla, namely, Gemmatimonadetes, Planctomycetes, Chlamydiae, Nitrospirae and Cyanobacteria which made up a more diverse microbial population in the OP cultivated area (Table 4).

Table 4 shows that species of Actinobacteria remained mostly prevalent in biodiversity strips area until 2013. Actinobacteria are prevalent in forest as they are attracted to abundant degrading organic materials like cellulose, lignin and chitin (Schafer et al., 2010). Acidobacteria were predominant at all sites and has been reported to be involved in microbial decomposition of lignocellulosic plant biomass (Eichorst et al., 2011). When the palms were at 4.5 to 5.5 years old, $\gamma$-Proteobacteria was prevalent in oil palm plantation, as it plays an important role in the decomposition of numerous soil $\mathrm{C}$ compounds. (Cleveland et al., 2007). The $\alpha$-Proteobacteria were mostly abundant in soil ecosystems rich in organic 


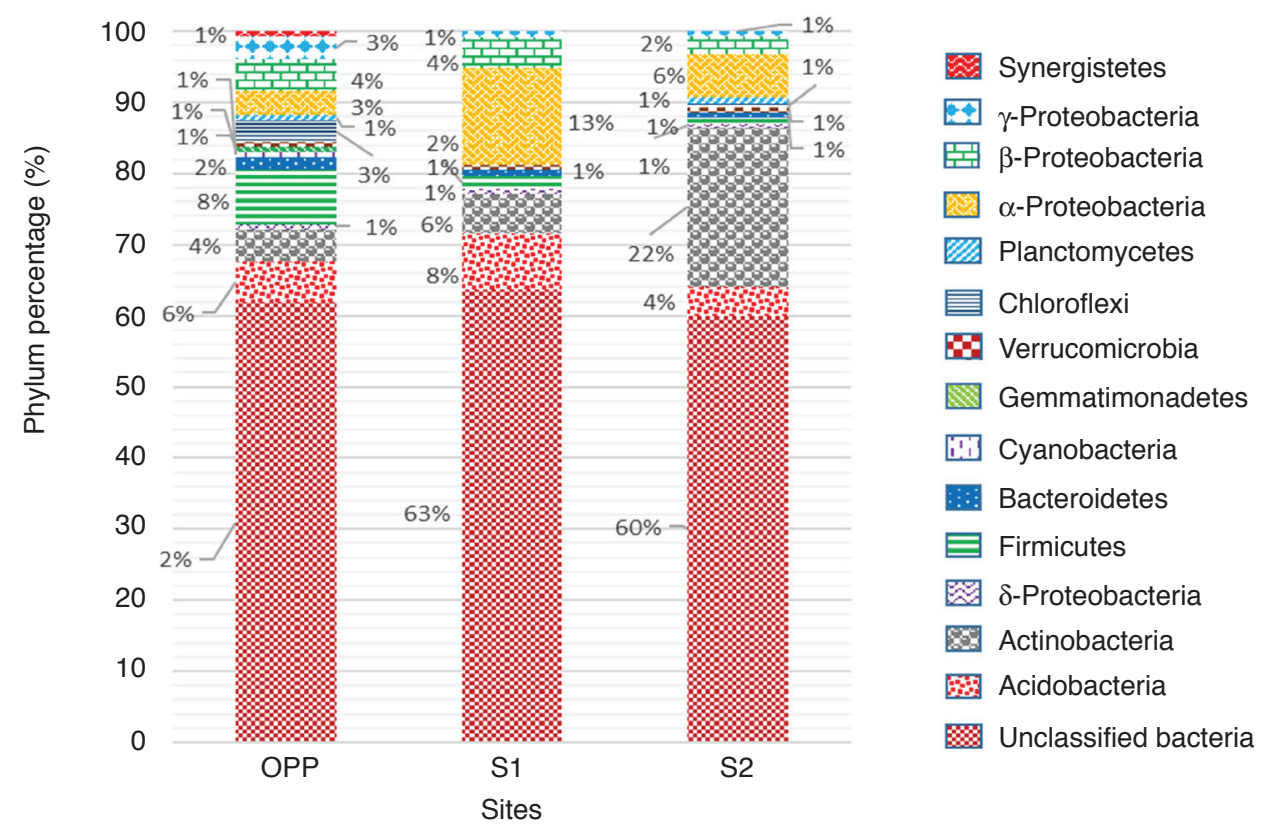

Note: (a) OPP - oil palm aged 4.5 years, (b) S1 - Strip 1, (c) S2 - Strip 2 and (d) S3 - Strip 3.

Figure 6. Prevalence of soil bacterial phyla at Belaga from July 2012 for biodiversity strips versus oil palm sampled from Sungai Asap, Belaga, Sarawak.
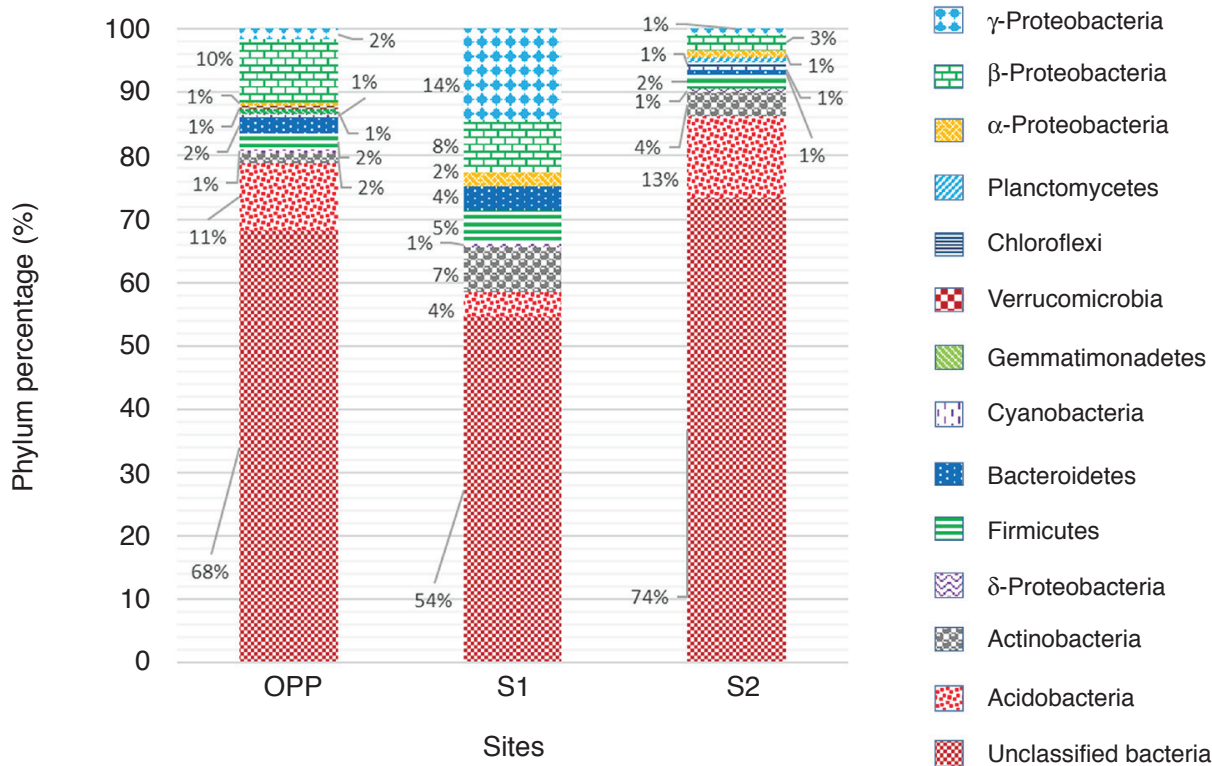

Note: (a) OPP - oil palm aged 5.5 years, (b) S1 - Strip 1, (c) S2 - Strip 2 and (d) S3 - Strip 3.

Figure 7. Prevalence of soil bacterial phyla at Belaga from June 2013 for biodiversity strips versus oil palm sampled from Sungai Asap, Belaga, Sarawak.

materials, playing a role as a nitrogen fixer but the group slightly decreased in OP area probably due to the slightly higher $\mathrm{pH}$ and low rainfall (Shange et al., 2012). During intercropping in 2012 to 2013, it was observed that major species of unclassified bacteria, Acidobacteria, $\gamma$-Proteobacteria, $\beta$-Proteobacteria and Bacteroidetes increased in species number (Table 4) in the OP areas. There was also presence of minor phyla $\delta$-Proteobacteria, Verrucomicrobia, Gemmatimonadetes, Planctomycetes, Synergistetes and Cyanobacteria compared to earlier planting of OP.

\section{Bacterial Community Composition Based on the Prevalent Phylum and Order Level under Different Ages of Oil Palm}

The analysis of the bacterial community composition (without the phylum unclassified bacteria) based on the prevalent phylum and order 
TABLE 4. TOTAL PROKARYOTIC SPECIES IN BELAGA, SARAWAK

\begin{tabular}{|c|c|c|c|c|c|c|c|}
\hline Sites & Phylum & 2008 & 2009 & 2010 & 2011 & 2012 & 2013 \\
\hline S1 & Unclassified & 3 & 6 & 6 & 9 & 20 & 12 \\
\hline S2 & bacteria & 4 & 6 & 7 & 5 & 14 & 12 \\
\hline S3 & & 3 & 4 & 6 & - & - & - \\
\hline OPP & & 6 & 8 & 11 & 8 & 19 & 21 \\
\hline S1 & Acidobacteria & 5 & 10 & 6 & 11 & 5 & 6 \\
\hline S2 & & 3 & 6 & 6 & 7 & 12 & 22 \\
\hline S3 & & - & 6 & 6 & - & - & - \\
\hline OPP & & 7 & 6 & 9 & 15 & 10 & 18 \\
\hline S1 & Actinobacteria & 5 & 51 & 31 & 35 & 56 & 41 \\
\hline S2 & & 18 & 64 & 14 & 13 & 75 & 42 \\
\hline S3 & & 16 & 58 & 47 & - & - & - \\
\hline OPP & & 14 & 10 & 28 & 67 & 49 & 27 \\
\hline S1 & $\alpha$-Proteobacteria & 9 & 14 & 9 & 23 & 144 & 18 \\
\hline S2 & & 3 & 2 & 33 & 5 & 55 & 18 \\
\hline S3 & & 3 & 32 & 19 & - & - & - \\
\hline OPP & & 16 & 35 & 37 & 28 & 60 & 15 \\
\hline S1 & Firmicutes & 32 & 5 & 12 & 20 & 16 & 27 \\
\hline S2 & & 2 & 5 & 2 & 5 & 6 & 8 \\
\hline S3 & & - & 13 & 4 & - & - & - \\
\hline OPP & & 30 & 75 & 11 & 22 & 42 & 4 \\
\hline S1 & $\gamma$-Proteobacteria & 3 & 11 & 18 & 3 & 5 & 48 \\
\hline S2 & & 2 & 6 & 4 & 15 & 1 & 5 \\
\hline S3 & & - & 29 & 4 & - & - & - \\
\hline OPP & & 2 & 8 & 17 & 8 & 35 & 34 \\
\hline $\mathrm{S} 1$ & $\beta$-Proteobacteria & - & 16 & 3 & 5 & 30 & 53 \\
\hline S2 & & - & 1 & 5 & 10 & 16 & 25 \\
\hline S3 & & - & 21 & 2 & - & - & - \\
\hline OPP & & 2 & 12 & 4 & 4 & 40 & 59 \\
\hline S1 & $\delta$-Proteobacteria & - & 4 & - & 1 & 2 & 2 \\
\hline S2 & & 1 & 1 & 1 & 1 & 2 & 3 \\
\hline S3 & & - & 2 & 1 & - & - & - \\
\hline OPP & & 2 & 1 & 2 & 1 & 4 & 8 \\
\hline S1 & Chloroflexi & 5 & 7 & 2 & 3 & 1 & - \\
\hline S2 & & 5 & 4 & 2 & 2 & 52 & \\
\hline S3 & & 5 & 1 & 6 & - & - & - \\
\hline OPP & & 5 & 3 & 9 & 9 & 13 & - \\
\hline S1 & Bacteroidetes & - & 6 & 2 & 3 & 2 & 31 \\
\hline S2 & & 1 & - & - & 2 & 4 & 4 \\
\hline S3 & & - & - & - & - & - & - \\
\hline OPP & & 1 & - & - & 9 & 53 & 9 \\
\hline S1 & Verrucomicrobia & - & - & - & 1 & 1 & - \\
\hline S2 & & - & 2 & - & - & 1 & - \\
\hline S3 & & 1 & 1 & - & - & - & - \\
\hline OPP & & - & 1 & - & 1 & 5 & 1 \\
\hline S1 & Gemmatimonadetes & - & 4 & - & 1 & - & - \\
\hline S2 & & - & - & - & - & - & - \\
\hline S3 & & - & - & 1 & - & - & - \\
\hline OPP & & - & - & - & - & 5 & 2 \\
\hline S1 & Planctomycetes & - & - & - & 2 & 3 & - \\
\hline S2 & & - & - & - & 5 & - & 1 \\
\hline S3 & & - & - & 1 & - & - & - \\
\hline OPP & & - & - & - & - & 1 & - \\
\hline S1 & Spirochaetes & - & - & - & - & - & - \\
\hline S2 & & - & 2 & - & - & - & - \\
\hline S3 & & - & 2 & - & - & - & - \\
\hline OPP & & - & - & - & - & - & - \\
\hline
\end{tabular}


TABLE 4. TOTAL PROKARYOTIC SPECIES IN BELAGA, SARAWAK (continued)

\begin{tabular}{|c|c|c|c|c|c|c|c|}
\hline Sites & Phylum & 2008 & 2009 & 2010 & 2011 & 2012 & 2013 \\
\hline S1 & Synergistetes & - & - & - & 3 & - & - \\
\hline S2 & & - & - & - & 2 & - & - \\
\hline S3 & & - & - & - & - & - & - \\
\hline OPP & & - & - & - & 1 & 2 & - \\
\hline S1 & Chlamydiae & - & - & - & - & - & - \\
\hline S2 & & - & - & - & 1 & - & - \\
\hline S3 & & - & - & - & - & - & - \\
\hline OPP & & - & - & - & 12 & - & - \\
\hline S1 & Cyanobacteria & - & - & - & 5 & - & - \\
\hline S2 & & - & - & - & 1 & - & 2 \\
\hline S3 & & - & - & - & - & - & - \\
\hline OPP & & - & - & 1 & - & 2 & 2 \\
\hline S1 & Nitrospirae & - & - & - & 1 & - & - \\
\hline S2 & & - & - & - & 1 & - & - \\
\hline S3 & & - & - & - & - & - & - \\
\hline OPP & & - & - & - & 1 & - & - \\
\hline S1 & Total & 62 & 130 & 89 & 117 & 288 & 238 \\
\hline S2 & & 39 & 99 & 74 & 80 & 191 & 145 \\
\hline S3 & & 27 & 169 & 98 & - & - & - \\
\hline OPP & & 85 & 159 & 116 & 186 & 293 & 230 \\
\hline
\end{tabular}

Note: OPP - oil palm plantation, S1- Biodiversity Strip 1, S2 - Biodiversity Strip 2, and S3 - Biodiversity Strip 3.

Palms age: 2008 - logged-over forest, 2009 - 1.5 years, 2010 - 2.5 years, 2011 - 3.5 years, 2012 - 4.5 years and 2013 - 5.5 years.

within the oil palm plantation revealed that the soil bacterial communities were diversified between the different ages of oil palm planting (Figure 8). Comparison of microbial order level revealed that in the logged-over forest (before cultivation) the most abundant was the unclassified Acidobacteria at $51 \%$ higher than in the oil palm planting areas. Other orders under the phylum Acidobacteria are Acidobacteriales $(7 \%)$ and Solibacteriales (2\%). Solibacteriales was only available in the logged-over forest area and was lacking in the oil palm planting area. Several studies show that Acidobacteria are mostly abundant in forest soils than in agricultural areas. Acidobacteria are oligotrophic microbes mostly dominant in carbon poor soils such as in forest soils as agricultural soil are rich in carbon and nitrogen (Nemergut et al., 2010). The proportion of Acidobacteria was described to be considerably lower in nutritional rich rhizosphere than in bulk soil, confirming their oligotrophic existence in the logged-over forest soil (Kielak et al., 2009). Recently the abundance of Acidobacteria was discovered to be negatively correlated with the nitrogen level in fertiliser (Fierer et al., 2012). The order Bacillales from Firmicutes was the second most abundant at $10 \%$ among the bacterial order before cultivation of oil palm.

After the land-clearing of the forest and planting of 1.5 year old palms, the order Bacillales was the most abundant at $48 \%$ for the phylum Firmicutes, followed by Burkholderiales, $12 \%$ for $\beta$-Proteobacteria and a significant increase of the phylum $\gamma$-Proteobacteria order Pseudomonadales at $6 \%$. The abundance of these phyla maybe correlated to the richness of soil $\mathrm{C}$ content after land-clearing confirming a study by Trivedi et al. (2016) that, soil $\mathrm{C}$ in soil corresponded with the relative abundance of Firmicutes, Verrucomicrobia, and Proteobacteria. The CIRP fertiliser applied during March to April 2009 which enhanced the phosphorus (P) level may also increase the abundance of Firmicutes with its ability to solubilise insoluble inorganic phosphate.

However, land-cleared activities also reduced the population of several phyla that were present in logged-over forest such as, Acidobacteria, Actinobacteria, $\alpha$-Proteobacteria and Chloroflexi. Acidobacteria was often associated with slightly higher $\mathrm{pH}$ in agricultural ecosystems compared to natural ecosystems (Rodrigues et al., 2013) hence the decrease in Acidobacteria population in 1.5 years old oil palm (Table 4). The $\alpha$-Proteobacteria displayed a negative correlation with the level of phosphorus in the soil. The genus Bradyrhizobium, in the order Rhizobiales of the phylum $\alpha$-Proteobacteria, was also strongly and negatively correlated with the level of $P$ in the soil (Herman et al., 2017). The group Chloroflexi prevails in nutritional poor soils (Will et al., 2010) and other oligotrophic ecosystems. Actinobacteria which is usually the most abundant phyla in all types of cultivated area, reduced in population in the clean-cleared areas due to the slight increase of $\mathrm{pH}$ to 4.8 (Table 5). The order Solirubrobacterales of Actinobacteria which were only present after clean-clearing, were considered 


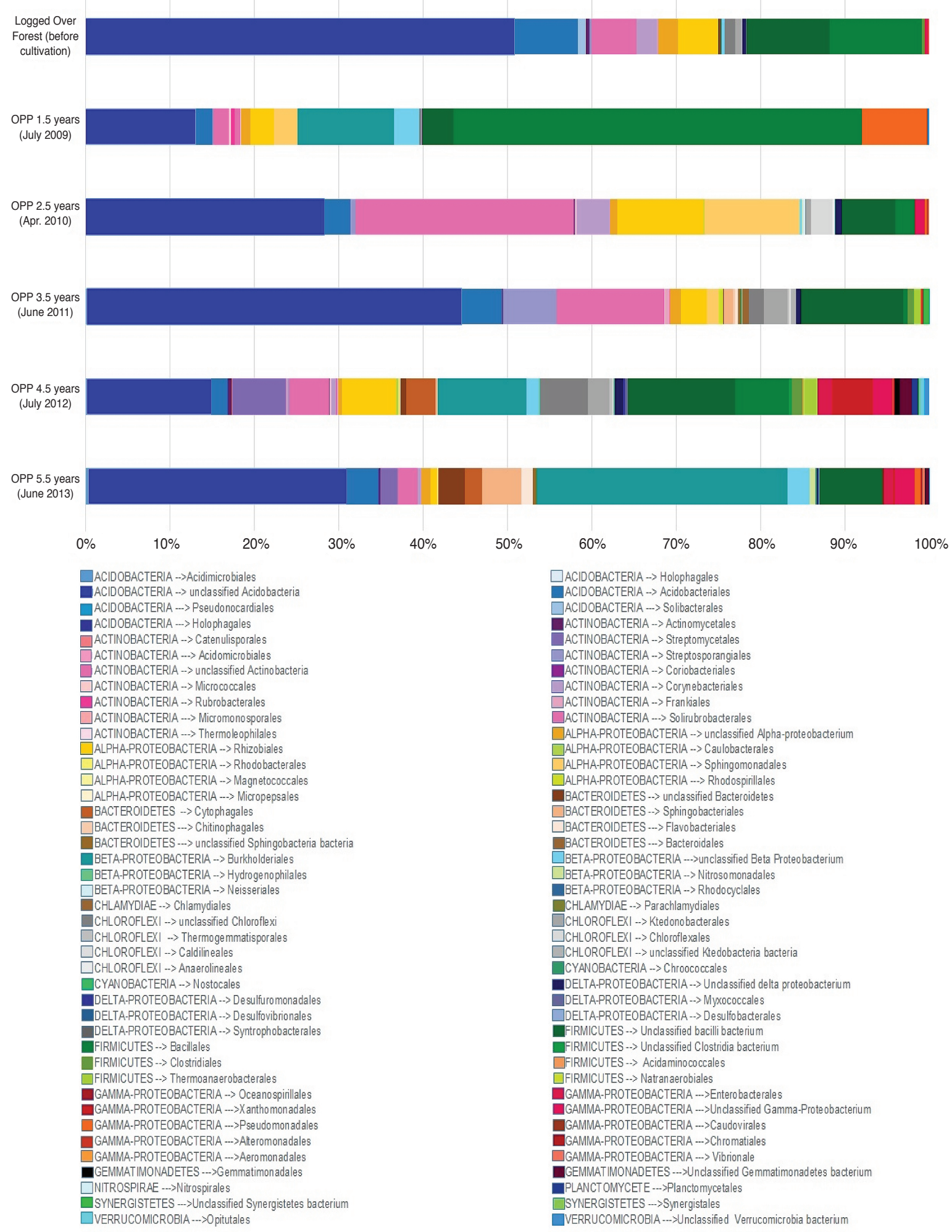

Note: The unclassified bacteria phylum was not included.

Figure 8. Bacterial community composition based on the prevalent phylum and order level under different ages of oil palm (OP).

as a biomarker to determine the effects on land use since the order seemed to favour physical disturbance where its abundance was usually related to the cultivated system (Shange et al., 2012).

When the palms were at 2.5 years, within the Actinobacteria, unclassified Actinobacteria and
Corynebacteriales exhibited higher abundances at $25 \%$ and $7 \%$, respectively. The phylum Actinobacteria produces numerous types of peroxidases (Le RoesHill et al., 2011) in which most are lignin peroxidases, accelerating humification and composting through hydrolysis of lignin into humic acid derivatives 
in a carbon and lignocellulosic rich environment. Among $\alpha$-Proteobacteria, Sphingomonadales was the most abundant with $12 \%$ and Rhizobiales, with $10 \%$. Sphingomonadales were more abundant in oil palm, possibly because this group preferred cultivation and the low $\mathrm{C} / \mathrm{N}$ ratio of the oil palm plantations (Kuramae et al., 2012).

When the oil palm reached 3.5 years, the phyla Acidobacteria orders increased for unclassified Acidobacteria, $43 \%$ and Acidobacteriales at $4 \%$, due to the slight acidic $\mathrm{pH}$ of the soil at $\mathrm{pH} 4.5$ (Table 5). The low $\mathrm{pH}$ may be due to the decomposition of organic matter in the surrounding area of the oil palm due to the accumulation of dried fronds and empty fruit bunches. Organic matter decomposed by microbes was converted directly into organic acid, carbon dioxide $\left(\mathrm{CO}_{2}\right)$ and water forming carbonic acid, which eventually resulted in more acidic soils. Within the phylum Actinobacteria, the order unclassified Actinobacteria increased at 25\% in abundance and there was presence of orders, Streptosporangiales and Pseudonocardiales with 7\% and 5\% abundance, respectively. The species in the order Streptosporangiales seems to originate from rare species of Actinobacteria and have the potential to produce new antibiotics (Lazzarini et al., 2000). Some Actinobacterial groups, from orders Frankiales and Pseudonocardiales are considered $\mathrm{N}_{2}$ fixing bacteria (Rughoft et al., 2016). Two other phyla with increasing presence were Chloroflexi with the order, Ktedonobacteriales, 3\% and Bacteroidetes with the order Sphingobacteriales, at 2\%. The presence of Bacteriodetes under cultivated systems may be associated with their capability in utilising organic matter and colonising soils shortly after crops are planted (Acosta-Martínez et al., 2008) whereas Chloroflexi thrived in oligotrophic ecosystems and the abundance of this photosynthetic phylum in oil palm plantation could be elucidated by the open canopy of the plantation which has greater exposure to sunlight than forest soils (Nacke et al., 2014)

At 4.5 years old, intercropping of pineapple and black pepper with oil palm showed increasing emergence of variability in phylum groups. With increasing $\mathrm{pH}$ of 4.9 , the population showed a rise in abundance of Firmicutes, $\beta$-Proteobacteria, $\gamma$-Proteobacteria, Chloroflexi, Bacteroidetes, and an increase in minor phylum of Verrucomicrobia, Gemmatimonadetes, Cyanobacteria and Planctomycete. The most abundant orders for Firmicutes were unclassified Bacilli, 13\%, followed by $\beta$-Proteobacteria with order Burkholderiales, $11 \%$, the phylum Gammaproteobacteria with order Xanthomonadales, $7 \%$ and Bacteroidetes with order Cytophagales at 5\%. The most abundant minor phylum was Chloroflexi with the order, unclassified Chloroflexi at 4\%, Gemmatimonadetes, with order unclassified Gemmatimonadetes, $2 \%$,
Verrucomicrobia with unclassified Verrucomicrobia, $2 \%, \delta$-Proteobacteria with unclassified Deltaproteobacteria, $2 \%$ and the emerging phylum Cyanobacteria and Planctomycete each with $1 \%$ abundance. There was also a presence of order Streptomycetales from Actinobacteria at 8\% abundance. Genera from Streptomyces spp. were the most abundant indicating possible signs of plant pathogens in the areas as these species have the ability to synthesise metabolites such as antibiotics in the presence of antagonistic microbes (Vaz Jauri et al., 2013). The phylum $\beta$-Proteobacteria showed an increase in abundance during oil palm at 4.5 and 5.5 years of age (Figure 8). The betaproteobacterial Burkholderiales seemed more abundant in oil palm plantations. The genera Burkholderia is one of the most important bacterial groups for nitrogen fixation in tropical soils, as a number of species are known to be plant associated nitrogen fixing bacteria (Estrada-De Los Santos et al., 2001). Within $\gamma$-Proteobacteria, Xanthomonadales were the predominant order, however, their abundance was not significantly different between forest and agricultural ecosystems (Schneider et al., 2015). Nemergut et al. (2010) revealed that the abundance of Bacteroidetes increased in fertilised agricultural soil compared to forest soils, as this group was positively correlated with soil $\mathrm{pH}$.

The important minor phylum, Chloroflexi are bacteria that is widely abundant in the terrestrial and aquatic ecosystems (Fierer et al., 2012) and the ecophysiological role of Chloroflexi is often associated with the nitrogen cycle, such as, nitrogen fixation and nitrite oxidation (Sorokin et al., 2012). Another important minor phylum, Cyanobacteria is also a nitrogen fixer, increases phosphorous availability and releasing auxins, promoting plant growth (Sharma et al., 2011). The number of photosynthetic Cyanobacteria increased in the oil palm plantations, probably due to the more exposed canopy of the oil palm plantations compared to rainforest, resulting in increased levels of light on the ground subsequently supporting growth of photosynthetically active bacteria. The fungi-like Myxococcales of the phylum $\delta$-Proteobacteria, which is more abundant in the agricultural soils is another indication of increased utilisation of organic fertilisation (dung) within managed agricultural systems (Brenner et al., 2005).

The minor phylum Gemmatimonadetes are ubiquitous in soil, however, they are reliant on moisture availability and studies reported members of this phylum are well adapted to low moisture environments (DeBruyn et al., 2011). Intercropping during these times may also increase population of functional rhizosphere soil bacteria, indicating a possible relation between increase yields of intercropping crops and microbes in comparison to monocropping (Yang et al, 2016). This is evident 
TABLE 5. LOCATIONS AND PHYSICO-CHEMICAL PROPERTIES OF SAMPLES STUDIED IN BELAGA, SARAWAK

\begin{tabular}{|c|c|c|c|c|}
\hline Sites & $\begin{array}{l}\text { Oil palm area } \\
(\mathrm{OP})\end{array}$ & $\begin{array}{l}\text { Biodiversity } \\
\text { Strip } 1 \text { (S1) }\end{array}$ & $\begin{array}{l}\text { Biodiversity } \\
\text { Strip 2(S2) }\end{array}$ & $\begin{array}{c}\text { Biodiversity } \\
\text { Strip 3(S3) }\end{array}$ \\
\hline Land type & Lowlands & $\begin{array}{c}\text { Undisturbed } \\
\text { secondary } \\
\text { jungle, hilly area }\end{array}$ & $\begin{array}{l}\text { Disturbed } \\
\text { secondary } \\
\text { jungle }\end{array}$ & $\begin{array}{l}\text { Riparian } \\
\text { area }\end{array}$ \\
\hline Sampling year & \multicolumn{4}{|c|}{ October 2008* (logged-over forest) } \\
\hline Rainfall & \multicolumn{4}{|c|}{$420 \mathrm{~mm}^{3}$} \\
\hline Moisture content & $16.4 \%$ & $20.0 \%$ & $4.3 \%$ & $24.6 \%$ \\
\hline $\mathrm{pH}$ & 4.7 & 4.5 & 4.7 & 5.1 \\
\hline Sampling year & \multicolumn{4}{|c|}{ July 2009 (1.5 years oil palm) } \\
\hline Rainfall & \multicolumn{4}{|c|}{$140 \mathrm{~mm}^{3}$} \\
\hline Moisture content & $22.7 \%$ & $35 \%$ & $33.0 \%$ & $16.0 \%$ \\
\hline $\mathrm{pH}$ & 4.8 & 4.4 & 4.3 & 5.1 \\
\hline Fertiliser application & $\begin{array}{l}\text { March-April } \\
\text { CIRP } 0.5 \mathrm{~kg}\end{array}$ & - & - & - \\
\hline Sampling year & \multicolumn{4}{|c|}{ April 2010 (2.5 years oil palm) } \\
\hline Rainfall & \multicolumn{4}{|c|}{$344.43 \mathrm{~mm}^{3}$} \\
\hline Moisture content & $22.1 \%$ & $40.3 \%$ & $43.1 \%$ & $31.5 \%$ \\
\hline $\mathrm{pH}$ & 4.7 & 4.6 & 4.2 & 4.6 \\
\hline Fertiliser application & $\begin{array}{c}\text { May-June } \\
\text { MPOB F1 } 0.8 \text { kg }\end{array}$ & - & - & - \\
\hline Sampling year & \multicolumn{4}{|c|}{ June 2011 (3.5 years oil palm) } \\
\hline Rainfall & \multicolumn{4}{|c|}{$158.76 \mathrm{~mm}^{3}$} \\
\hline Moisture content & $28.6 \%$ & $34.6 \%$ & $37.2 \%$ & - \\
\hline $\mathrm{pH}$ & 4.5 & 4.3 & 4.3 & - \\
\hline Fertiliser application & $\begin{array}{c}\text { Feb-May-Aug-Nov } \\
\text { MPOB F1 } 1.75 \text { kg }\end{array}$ & - & - & - \\
\hline Sampling year & \multicolumn{4}{|c|}{ July 2012 (4.5 years oil palm) } \\
\hline Rainfall & \multicolumn{4}{|c|}{$302.770 \mathrm{~mm}^{3}$} \\
\hline Moisture content & $26.9 \%$ & $46.6 \%$ & $43.1 \%$ & - \\
\hline $\mathrm{pH}$ & 4.9 & 4.5 & 4.2 & - \\
\hline Fertiliser application & $\begin{array}{l}\text { Feb-May-Aug-Nov } \\
\text { MPOB F1 } 1.75 \text { kg }\end{array}$ & - & - & - \\
\hline Sampling year & \multicolumn{4}{|c|}{ June 2013 (5.5 years oil palm) } \\
\hline Rainfall & \multicolumn{4}{|c|}{$98.89 \mathrm{~mm}^{3}$} \\
\hline Moisture content & $24.3 \%$ & $36.3 \%$ & $33.0 \%$ & - \\
\hline $\mathrm{pH}$ & 4.6 & 4.4 & 4.1 & - \\
\hline Fertiliser application & $\begin{array}{c}\text { Feb-May-Aug-Nov } \\
\text { MPOB F1 } 1.75 \text { kg }\end{array}$ & & & \\
\hline
\end{tabular}

in the increase of microbial species number and variants shown, from 4.5 years to 5.5 years. (Table 4 ).

Under dry season during June 2013, the numbers of Actinobacteria was reduced, suggesting that increases in respiration caused by high temperatures (Luo, 2007) may be negatively affecting this phylum as they are well-known to be sensitive to increased $\mathrm{CO}_{2}$ (Goodfellow and Williams, 1983). Furthermore, at 5.5 years old, the slight abundance of Acidobacteria might be the cause of reduced population in Actinobacteria, as these two phyla share the same niches. The slight increase in the presence of Nitrosomonadales at 2\% abundance, a well-known, ammonia-oxidising bacteria (Shen et al.,
2012), also correlated with the increased treatment of fertiliser in intensively managed plantations in oil palm of 5.5 years old. The $\beta$-Proteobacteria was the phylum with the most increase in abundancy of up to $30 \%$, mostly from the order Bukholderiales. Bukholderiales has a range of roles in soil functions, such as, plant growth promoters (Estrada-De Los Santos et al., 2001), nitrogen fixers (Gyaneshwar et al., 2011) and biocontrol agents against plant pathogens. The phylum Bacteroidetes also increased to $10 \%$ abundance which played a role in plant growth promotion (Soltani et al., 2010) and cellulose degradation (Verkhovtseva et al., 2007), amongst other functions. 


\section{Relationships between Bacterial Community Structure with Different Oil Palm Age}

In the PCA, the analysis on the data collected on microbial community structure, biodiversity index and physico-chemical properties was carried out to see the correlation between age of oil palm, soil properties and prevalent types of microbial community present. The first and second principal components explain the substantial variation between these soil samples with prevalent phylum and soil properties, occurring in the oil palm soil (F1 varied by $42.05 \%$ while F2 varied by $29.59 \%$ ). Microbial community structure and abundance with soil physico-chemical properties were correlated with the major axes of the different oil palm age (Figure 9). The upper right hand quadrant shows the increased abundance of phylum Synergistetes, Actinobacteria, Cyanobacteria, Gemmatimonadetes, Chloroflexi, Verrucomicrobia Planctomycete, Gammaproteobacteria and Alphaproteobacteria in 4.5-year old oil palms area. These groups are positively correlated with soil moisture content. Another positive correlation is with the phylum groups in the 3.5 and 5.5 years old oil palm, where this quadrant exhibits the increase abundance of Betaproteobacteria, Bacteroidetes, Acidobacteria, Deltaproteobacteria, Nitrospirae and Chylamidae. The abundance of these bacteria phylae are correlated with fertiliser applications $(\mathrm{kg})$. Shannon-Weaver index $\left(\mathrm{H}^{\prime}\right)$, had greater values in 3.5 and 5.5 years old oil palm. The last quadrant on the upper left consisting of early age oil palm of logged-over forest, 1.5 and 2.5 years old oil palm was only predominant with the phylum Firmicutes in correlation with rainfall and $\mathrm{pH}$. Logged-over forest, furthermost to the left had the least value in microbial biodiversity $\left(\mathrm{H}^{\prime}\right)$. Overall, the clusters in PCA corresponds to the relative abundances of phylum occurring in the different oil palm age areas associated with soil parameters $\mathrm{pH}$, moisture content, rainfall and fertiliser regime.

In this present study, it was shown that the bacterial composition in biodiversity strips, secondary logged-over forest was mostly predominated by Acidobacteria, followed by Actinobacteria and $\alpha$-Proteobacteria whereas oil palm management areas towards oil palm aged 5.5 years were most commonly consisted of Firmicutes, $\beta$-Proteobacteria, Actinobacteria, Acidobacteria, Bacteroidetes and Chloroflexi. In the oil palm plantation, there seem to be shifts in the bacterial community especially with the increasing number of the phylum Firmicutes, $\beta$-Proteobacteria, Bacteroidetes and decreasing number of $\alpha$-Proteobacteria. The changes in abundance of these phylae is from the slight increase of $\mathrm{pH}$ values where it might be the reason for the most prominent observed changes within the Firmicutes,
$\beta$-Proteobacteria and $\alpha$-Proteobacteria. Several studies indicated that soil bacterial community shifts after rainforest conversion were caused by fertiliser application, liming and reduction of plant diversity (Abdi et al., 2016; Val-Moraes et al., 2016; Liu et al., 2017). We also detected the nitrification-related phylum Nitrospirae with genus Nitrospirales in oil palm aged 3.5 years, where this genus is exclusively found in the oil palm plantations (Lücker et al., 2010; Ma et al., 2013). This genus signifies higher degrees of nitrification in oil palm soils compared to rainforest, probably caused by fertiliser application and correspondingly nitrogen input, leading to more favourable conditions for nitrifiers (Ma et al., 2013; Quan et al., 2016). The fertiliser regime increased certain bacteria population such as Firmicutes which was prevalent in the oil palm area with 1.5-year old palms where the application of fertiliser increased the $\mathrm{pH}$ and phosphate level in the soil (Table 5).

The bacterial community composition data revealed that the phyla responding to agricultural land use were associated with soil parameters such as, $\mathrm{pH}$, fertiliser regime and rainfall. In a newly developed oil palm plantation, $\mathrm{pH}$ factors affected several phyla especially Acidobacteria, where a slight increase would reduce its abundancy whereas with increasing $\mathrm{pH}$, the population showed an abundance of Firmicutes, $\beta$-Proteobacteria, $\gamma$-Proteobacteria, Chloroflexi, and Bacteroidetes. Slight disturbance in $\mathrm{pH}$ and addition of fertiliser during landclearing for newly developed oil palm plantation altered the bacteria composition where Firmicutes largely dominated the 1.5-year oil palm area. The biodiversity index and bacterial community composition gradually increased in variation after land-clearing. Rainfall influenced the phylum group Actinobacteria during the dry season in June 2013, where higher temperature increased $\mathrm{CO}_{2}$ in which this group is recognised to be sensitive to high levels of $\mathrm{CO}_{2}$ (Goodfellow and Williams, 1983).

In agricultural soils, changes of soil physicochemical factors introduced by field management such as repeated fertiliser application often increases the salt content in the soil, hence, altering the $\mathrm{pH}$ of the surrounding environment, and in consequence, affecting bacterial composition and probably changes in bacterial functioning. Even though this is the case, nutrient inputs by fertiliser improves overall plant growth, increases accumulation of soil organic matter leading to improvement in soil quality (Smith et al., 2016). There is a need for further research in using sustainable methods such as a suitable intercropping system that can positively improve soil fertility and a balanced long-term usage of biofertilisers and chemical fertilisers, which can enhance the biodiversity of the bacterial community and contributes to the sustainable development of agro-ecosystems. 
Biplot (axes F1 and F2: 71.64\%)

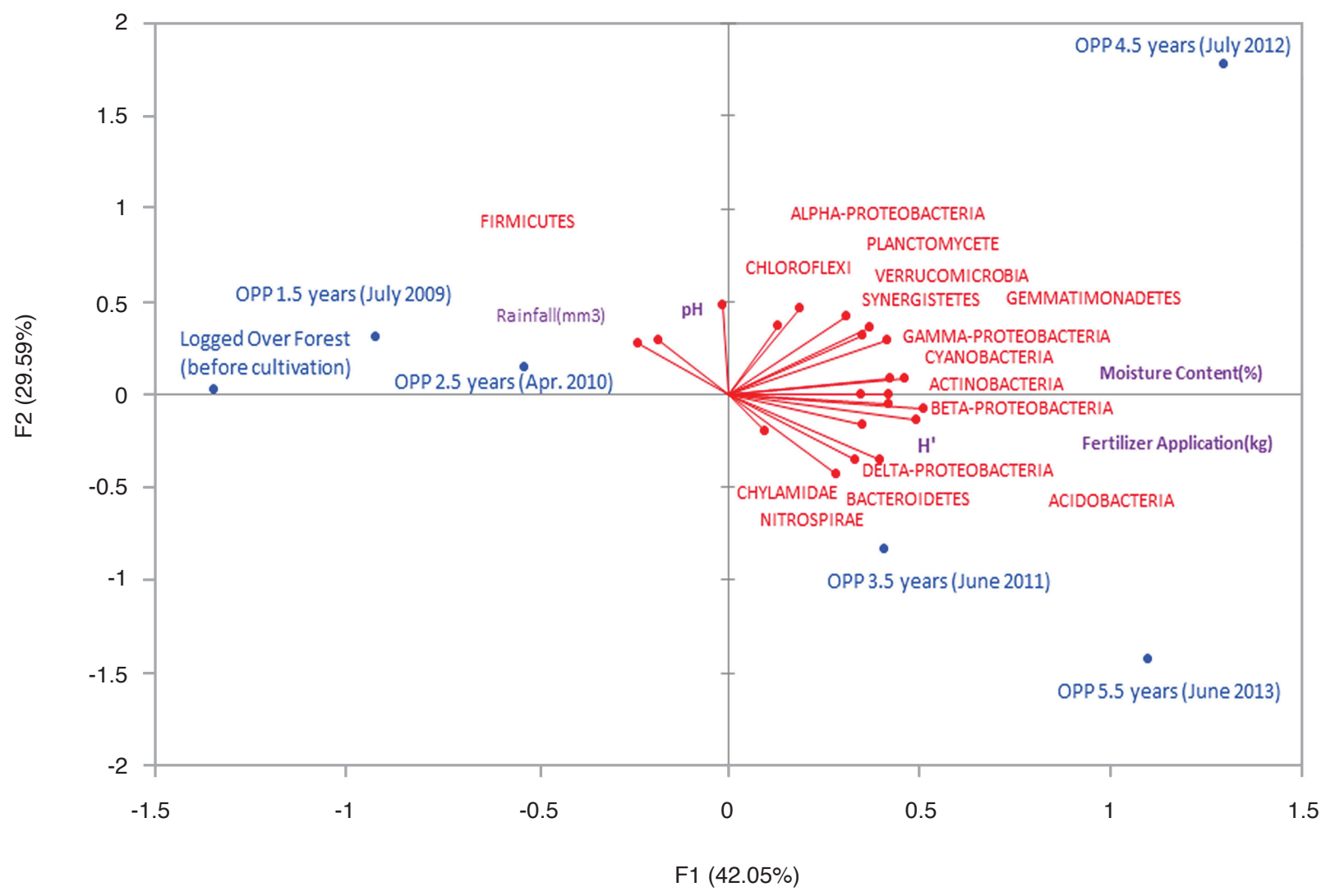

Note: $\mathrm{H}^{\prime}$ - Shannon-Weaver Biodiversity index.

Figure 9. Relationships between microbial community structure with physico-chemical properties in different oil palm age in Belaga, Sarawak from principal components analysis (PCA) using Pearson correlation.

\section{CONCLUSION}

In summary, our study revealed that soil physicochemical factors, especially $\mathrm{pH}$, fertiliser application, rainfall and incorporation of intercropping systems were the key factors explaining the variance in bacterial communities, in the field management of oil palm. Shifts in the bacterial community especially with the increasing number of the phylum Firmicutes, $\beta$-Proteobacteria, Bacteroidetes and the decreasing number of $\alpha$-Proteobacteria caused by the slight increase of $\mathrm{pH}$ values indicated that changes of soil properties introduced by field management (e.g., fertiliser application) somehow affects bacterial composition. Nevertheless, the sustainable method of intercropping oil palm with black pepper and pineapple, showed increasing emergence of variability in minor phylum groups which indicates this method as a sustainable system in the oil palm management. Overall, however, upcoming researches should also focus on functional changes related with shifts in the bacterial composition with developed methods in soil metagenomics or next generation sequencing, something not addressed in this study. There's also a need to explore researches in sustainable methods in field management such as intercropping to improve fertility and balanced usage of organic or biofertiliser with chemical fertiliser to enhance the biodiversity of bacterial community which contributes to the sustainable development of oil palm plantations.

\section{ACKNOWLEDGEMENT}

The authors would like to thank the DirectorGeneral of MPOB for permission to publish this article. The authors would also like to extend their gratitude to Dr Siti Ramlah Ahmad Ali for reviewing the manuscript and further gratitude also goes to the MPOB Board members for funding the project under budget code; Q001205001.

\section{REFERENCES}

Abdi, D; Ziadi, N; Shi, Y; Gagnon, B; Lalande, R and Hamel, C (2016). Residual effects of paper mill 
biosolids and liming materials on soil microbial biomass and community structure. Can. J. Soil. Sci., 97: 188-199.

Acosta-Martínez, V; Dowd, S E; Sun, Y and Allen, V G (2008). Tag-encoded pyrosequencing analysis of bacterial diversity in a single soil type as affected by management and land use. Soil Biol. Biochem., 40: 2762-2770.

Agnieszka, W; Zofia, S; Aleksandra, B and Artur, B (2012a). Evaluation of factors influencing the biomass of soil microorganisms and DNA content. Open J. Soil Science, 2: 64-69.

Brenner, D J; Krieg, N R; Staley, J T and Garrity, G M (2005). Bergey's Manual of Systematic Bacteriology. Vol. 2, Part C. New York, NY: Springer. 304 pp.

Burgin, A J; Yang, W H; Hamilton, S K and Silver, W L (2011). Beyond carbon and nitrogen: How the microbial energy economy couples elemental cycles in diverse ecosystems. Frontiers in Ecology and the Environment, 9: 44-52.

Caporaso, J G; Lauber, C L; Walters, W A; BergLyons, D; Lozupone, C A; Turnbaugh, P J; Fierer, N and Knight, R (2011). Global patterns of 16S rRNA diversity at a depth of millions of sequences per sample. Proc. of the Nat. Acad. Sci. USA, 108: 45164522.

Carlson, K M; Curran, L M; Asner, G P; Mcdonald Pittman, A; Trigg, SN and Adeney, J M (2012). Carbon emissions from forest conversion by Kalimantan oil palm plantations. Nat. Clim. Change, 3: 283-287.

Cleveland, C C; Nemergut, D R; Schmidt, S K and Townsend, A R (2007). Increases in soil respiration following labile carbon additions linked to rapid shifts in soil microbial community composition. Biogeochemistry, 82: 229-240.

Curtis, T P; Sloan, W T and Scannell, J W (2002). Estimating prokaryotic diversity and its limits. Proc. of the Natl Acad. Sci. USA, 99: 10494-10499.

Debruyn, J M; Nixon, L T; Fawaz, M N; Johnson, A M and Radosevich, M (2011). Global biogeography and quantitative seasonal dynamics of Gemmatimonadetes in soil. Appl. Environ. Microbiol, 77: 6295-6300.

Dilly, O; Bloem, J; Vos, A and Munch, J C (2004). Bacterial diversity in agricultural soils during litter decomposition. Appl. Environ. Microbiol., 70 (1): 486-474.

Ding, G C; Piceno, Y M; Heuer, H; Weinert, N; Dohrmann, A B; Carrillo, A; Andersen, G L;
Castellanos, T; Tebbe, C C and Smalla, K (2013). Changes of soil bacterial diversity as a consequence of agricultural land use in a semi-arid ecosystem. PLOS ONE, 8: e59497.

Dubinsky, E A; Silver, W L and Firestone, M K (2010). Tropical forest soil microbial communities couple iron and carbon biogeochemistry. Ecology, 91: 2604-2612.

Eichorst, S A; Kuske, C R and Schmidt, T M (2011). Influence of plant polymers on the distribution and cultivation of bacteria in the phylum acidobacteria. Applied Environmental Microbiology Vol. 77(2): 586-596.

Estrada-De Los Santos, P; Bustillos-Cristales, R and Caballero-Mellado, J (2001). Burkholderia, a genus rich in plant-associated nitrogen fixers with wide environmental and geographic distribution. Applied and Environmental Microbiology, 67(6): 2790-2798.

Fierer, N; Bradford, M A and Jackson, R B (2007a). Toward an ecological classification of soil bacteria. Ecology, 88: 1354-1364.

Fierer, N; Breitbart, M; Nulton, J; Salamon, P; Lozupone, C; Jones, R; Robeson, M; Edwards, R A; Felts, B; Rayhawk, S; Knight, R; Rohwer, F and Jackson, R B (2007b). Metagenomic and smallsubunit rRNA analyses reveal the genetic diversity of bacteria, archaea, fungi, and viruses in soil. Applied and Environmental Microbiology, 73: 7059-7066.

Fierer, N; Lauber, C L; Ramirez, K S; Zaneveld, J and Bradford, M A (2012). Comparative metagenomic, phylogenetic and physiological analyses of soil microbial communities across nitrogen gradients. ISME J., 6: 1007-1017.

Goodfellow, M and Williams, S T (1983). Ecology of Actinomycetes. Annu. Rev. Microbiol., 37: 189-216.

Gyaneshwar, P; Hirsch, A M; Moulin, L; Chen, W M; Elliott, G N; Bontemps, C; Estrada-De Los Santos, P; Gross, E; Dos Reis, F B; Sprent, J I; Young, J P W and James, E K (2011). Legume-nodulating betaproteobacteria: Diversity, host range, and future prospects. Mol. Plant-Microbe Interact., 24: 1276-1288.

Hayat, R; Ali, S; Amara, U; Khalid, R and Ahmed, I (2010). Soil beneficial bacteria and their role in plant growth promotion: A review. Annals of Microbiology, 60 (4): 579-598.

$\mathrm{He}, \mathrm{J}$; Xu Z and Hughes, J (2006). Molecular bacterial diversity of a forest soil under residue management regimes in subtropical Australia. FEMS Microbiol. Ecol., 55: 38-47. 
Herman, S M; Buckley, H L; Case, B S; CurranCournane, F; Taylor, M and Lear, G (2017). Bacteria as emerging indicators of soil condition. Applied and Environmental Microbiology, 83: e02826-e02816.

Hill, M O (1973). Diversity and evenness: a unifying notation and its consequences. Ecology, 54: 427-431.

Hilton, S; Bennett, A J; Keane, G; Bending, G D; Chandler, D; Stobart, R and Mills, P (2013). Impact of shortened crop rotation of oilseed rape on soil and rhizosphere microbial diversity in relation to yield decline. PLoS ONE, 8: e59859.

Kielak, A; Pijl, A S; Van Veen, J A and Kowalchuk, G A (2009). Phylogenetic diversity of Acidobacteria in a former agricultural soil. ISME J., 3: 378-382.

Koh, L P; Miettinen, J; Liew, S C and Ghazoul, J (2011). Remotely sensed evidence of tropical peatland conversion to oil palm. Proc. of the Natl. Acad. Sci. USA, 108: 5127-5132.

Kuramae, E E; Yergeau, E; Wong, L C; Pijl, A S; Van Veen, J A and Kowalchuk, G A (2012). Soil characteristics more strongly influence soil bacterial communities than land-use type. FEMS Microbiol. Ecol., 79: 12-24.

Kushairi, A; Soh Kheang Loh; Azman, I; Elina Hishamuddin; Meilina Ong-Abdullah; Zanal Bidin Mohd Noor Izuddin; Razmah, G; Shamala Sundram and Ghulam Kadir Ahmad Parveez (2018). Oil palm economic performance in Malaysia and R\&D progress in 2017. J. Oil Palm Res. Vol.30 (2): 163-195.

Lazzarini, A; Cavaletti, L; Toppo, G and Marinelli, F (2000). Rare genera of actinomycetes as potential producers of new antibiotics. Antonie van Leeuwenhoek, 78(3): 399-405.

Le Roes-Hill, M; Khan, N and Burton, S G (2011). Actinobacterial peroxidases: An unexplored resource for biocatalysis. Appl. Biochem. Biotechnol., 164: 681-713.

Liu, X; Chen, C; Hughes, J; Wang, W and Lewis, T (2017). Temporal changes rather than long-term repeated burning predominately control the shift in the abundance of soil denitrifying community in an Australian sclerophyll forest. Microb. Ecol., 73: 177-187.

Lücker, S; Wagner, M; Maixner, F; Pelletier, E; Koch, $\mathrm{H}$ and Vacherie, B (2010). A nitrospira metagenome illuminates the physiology and evolution of globally important nitrite-oxidizing bacteria. Proc. of the Natl. Acad. Sci. USA, 107: 13479-13484.
Luo, Y (2007). Terrestrial carbon cycle feedback to climate warming. Annu. Rev. Ecol. Evol Syst., 38: 683712 .

Ma, J; Wang, Z; Zhu, C; Liu, S; Wang, Q and Wu, Z (2013). Analysis of nitrification efficiency and microbial community in a membrane bioreactor fed with low COD/N-Ratio wastewater. PLoS ONE, 8: e63059.

Muyzer, G; De Waal, E C and Uitterlinden, A G (1993). Profiling of complex microbial populations by denaturing gradient gel electrophorhesis analysis of polymerase chain reaction-amplified genes coding for 16S rRNA. Applied and Environmental Microbiology, 59(3): 695-700.

Nacke, H; Fischer, C; Thürmer, A; Meinicke, P and Daniel, R (2014). Land use type significantly affects microbial gene transcription in soil. Microb. Ecol., 67: 919-930.

Nemergut, D R; Cleveland, C C; Wieder, W R; Washenberger, C L and Townsend, A R (2010). Plotscale manipulations of organic matter inputs to soils correlate with shifts in microbial community composition in a lowland tropical rain forest. Soil Biol. Biochem., 42: 2153-2160.

Nielsen, U N; Ayres, E; Wall, D H and Bardgett, R D (2011). Soil biodiversity and carbon cycling: A review and synthesis of studies examining diversityfunction relationships. Eur. J. Soil Sci., 62: 105-116.

Oulas, A; Pavloudi, C; Polymenakou, P; Pavlopoulos, G A; Papanikolaou, N and Kotoulas, G (2015). Metagenomics: Tools and insights for analyzing next-generation sequencing data derived from biodiversity studies. Bioinform Biol. Insights, 9: 75-88.

Quan, Z; Huang, B; Lu, C; Shi, Y; Chen, X and Zhang, H (2016). The fate of fertilizer nitrogen in a high nitrate accumulated agricultural soil. Sci. Rep., 6: 21539.

Rodrigues, J L M; Pellizari, V H; Mueller, R; Baek, K; Jesus, E D C, and Paula, F S (2013). Conversion of the Amazon rainforest to agriculture results in biotic homogenization of soil bacterial communities. Proc. of the Natl. Acad. Sci. USA, 110(3): 988-993.

Rughoft, S; Herrmann, M; Lazar, C S; Cesarz, S; Levick, S R; Trumbore, S E and Küsel, K (2016). Community composition and abundance of bacterial, archaeal and nitrifying populations in Savanna soils on contrasting bedrock material in Kruger National Park, South Africa. Frontiers in Microbiology, 7: 1638. 
Schafer, J; Jackel, U and Kampfer, P (2010). Development of a new PCR primer system for selective amplifiation of Actinobacteria. FEMS Microbiol. Lett., 311: 103-112.

Schneider, D; Engelhaupt, M; Allen, K; Kurniawan, S; Krashevska, V; Heinemann, M; Scheu, S and Daniel, R (2015). Impact of lowland rainforest transformation on diversity and composition of soil prokaryotic communities in Sumatra (Indonesia). Frontiers in Microbiology, 6: 1339.

Shange, R S; Ankumah, R O; Ibekwe, A M; Zabawa, R and Dowd, S E (2012). Distinct soil bacterial communities revealed under a diversely managed agroecosystem. PLoS ONE, 7(7): e40338. https:// doi.org/10.1371/journal.pone.0040338

Sharma, N K; Tiwari, S P; Tripathi, K and Rai, A K (2011). Sustainability and cyanobacteria (blue-green algae): Facts and challenges. J. Appl. Phycol., 23: 1059-1081.

Shen, J P; Zhang, L M; Di, H J and He, J Z (2012). A review of ammonia oxidizing bacteria and archaea in Chinese soils. Front. Microbiol., 3: 296.

Smith, P; House, J I; Bustamante, M; Sobocká, J; Harper, R; Pan, G; West, P C; Clark, J M; Adhya, T; Rumpel, C; Paustian, K; Kuikman, P; Cotrufo, M F; Elliott, J A; Mcdowell, R; Griffiths, R I; Asakawa, S; Bondeau, A; Jain, A K; Meersmans, J and Pugh, T A M (2016). Global change pressures on soils from land use and management. Glob. Change Biol., 22: 1008-1028.

Soltani, A A; Khavazi, K; Asadi-Rahmani, H; Omidvari, M; Abaszadeh, D P and Mirhoseyni, H (2010). Plant growth promoting characteristics in some Flavobacterium spp. isolated from soils of Iran. J. Agr. Sci., 4: 106-115.

Sorokin, D Y; Lücker, S; Vejmelkova, D; Kostrikina, N A; Kleerebezem, R; Rijpstra, W I C and Daims, H (2012). Nitrification expanded: Discovery, physiology and genomics of a nitrite-oxidizing bacterium from the phylum Chloroflexi. The ISME J., 6(12): 2245-2256.

Suleiman, A K; Manoeli, L; Boldo, J T; Pereira, M G and Roesch, L F (2013). Shifts in soil bacterial community after eight years of land-use change. Syst. Appl. Microbiol., 36: 137-144.
Trivedi, P; Delgado-Baquerizo, M; Anderson, I C and Singh, B K (2016). Response of soil properties and microbial communities to agriculture: implications for primary productivity and soil health indicators. Frontiers in Plant Science, 7: 990.

Val-Moraes, S P; De Macedo, H S; Kishi, L T; Pereira, R M; Navarrete, A A and Mendes, L W (2016). Liming in the sugarcane burnt system and the green harvest practice affect soil bacterial community in northeastern Sao Paulo, Brazil. Antonie Van Leeuwenhoek, 109: 1643-1654.

Van Der Heijden, M G A; Bardgett, R D and Van Straalen, N M (2008). The unseen majority: Soil microbes as drivers of plant diversity and productivity in terrestrial ecosystems. Ecol. Lett., 11: 296-310.

Vaz Jauri, P; Bakker, M G; Salomon, C E and Kinkel, L L (2013). Subinhibitory antibiotic concentrations mediate nutrient use and competition among soil streptomyces. PLoS ONE, 8(12): e81064.

Verkhovtseva, N; Kubarev, E and Mineev, V (2007). Agrochemical agents in maintaining the structure of the soil microbial community. Russ. Agric. Sci., 33: 100-102.

Wakelin, S A; Macdonald, L M; Rogers, S L; Gregg, A L; Bolger, T P and Baldock, J A (2008). Habitat selective factors influencing the structural composition and functional capacity of microbial communities in agricultural soils. Soil Biol. Biochem., 40: 803-813.

Will, C; Thurmer, A; Wollherr, A; Nacke, H and Herold, N (2010). Horizon specific bacterial community composition of German grassland soils, as revealed by pyrosequencing-based analysis of $16 \mathrm{~S}$ rRNA genes. Appl. Environ. Microbiol., 76: 6751-6759.

Yang, Z; Yang, W; Li, S; Hao, J; Su, Z and Sun, M (2016). Variation of bacterial community diversity in rhizosphere soil of sole-cropped versus intercropped wheat field after harvest. PLOS ONE, 11(3): e0150618.

Zhang, K; Cheng, X; Dang, H; Ye, C; Zhang, Y and Zhang, Q (2013). Linking litter production, quality and decomposition to vegetation succession following agricultural abandonment. Soil Biol. Biochem., 57: 803-813. 